\title{
Angles
}

New Perspectives on the Anglophone World

$8 \mid 2019$

Neoliberalism in the Anglophone World

\section{"To mutiny against this servitude": The Sophisticated Democracy of As You Like It}

\section{Ifig Cocoual}

\section{Q OpenEdition}

1 Journals

\section{Electronic version}

URL: https://journals.openedition.org/angles/665

DOI: $10.4000 /$ angles.665

ISSN: 2274-2042

\section{Publisher}

Société des Anglicistes de l'Enseignement Supérieur

\section{Electronic reference}

Ifig Cocoual, "'To mutiny against this servitude": The Sophisticated Democracy of As You Like It", Angles [Online], 8 | 2019, Online since 01 April 2019, connection on 07 June 2022. URL: http:// journals.openedition.org/angles/665 ; DOI: https://doi.org/10.4000/angles.665

This text was automatically generated on 7 June 2022.

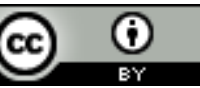

Angles est mise à disposition selon les termes de la Licence Creative Commons Attribution 4.0 International. 


\title{
"To mutiny against this servitude": The Sophisticated Democracy of As You Like It
}

\author{
Ifig Cocoual
}

Poetry is a kind of popular oratory [...]. [D]on't
you think poets are the rhetoricians of the

theatre?

(Plato, Gorgias: 502c-d)

1 "Form serves as a necessary bridge to new, still unknown content" (Bakhtin 1986: 165), Bakhtin tells us, and As You Like It's dramatic and linguistic forms tell a politicalphilosophical story that is at odds with the conservative restoration plot in which hierarchy is reaffirmed (5.4.156-9) ${ }^{1}$ after the pastoral interval. Although the play may seem to be an innocuously apolitical or ultimately conservative pastoral-romantic comedy, this paper suggests that its rhetoric and poetics, as well as some easily overlooked plot points, may well make it radically democratic.

2 If literature, no matter how seemingly autotelic, can always be read politically or as political, Elizabethan literature, and drama in particular, "was an especially important form for advancing political debate" (Hadfield 2008: 7) because key issues could not be discussed in the open, and "the theaters [were a] location of Renaissance deliberative [i.e "political"] rhetoric" (Platt 1999: 281). As for Shakespeare, from The Rape of Lucrece to Julius Caesar and Antony and Cleopatra, he "narrate[d] more of the republican story than any other dramatist working in Elizabethan and Jacobean England." (Hadfield 2008: 57)

3 As it turns out, the republican icon "Lucretia", whose tragic fate helped give birth to the Roman republic, crops up in As You Like It (3.3.123), though in a list within a poem which might make its political importance less obvious; this, however, could be how the play as a whole works, and if we agree that ancient and contemporary (not just Elizabethan) contexts can help make sense(s) of the play's poetics and politics, it is far from politically insignificant. 


\title{
"Tyrant duke" and "tyrant brother" (1.2.240)
}

\author{
[I am] persuaded that the poet devised the \\ eclogue [...] not of purpose to counterfeit or \\ represent the rustical manner of loves and \\ communication, but under the veil of homely \\ persons and in rude speeches to insinuate and glance \\ at greater matters, and such as perchance had not \\ been safe to have been disclosed in any other sort. \\ (Puttenham 2007: 127-8, emphasis added)
}

The conflicts which drive the romantic characters to Arden are often explained away as the kind of artificial plot device which the play also resorts to in its contrived dénouement and elaborate showboat of a finale. There are several hints, however, that the aggression Rosalind and Orlando endure is anything but gratuitous and that the villains' motivations are at least, in part, political - hints, that is, that Duke Frederick and Oliver feel threatened by popular figures and by the people's judgment.

Oliver, the contradictions or ambiguities of whose patriarchal-aristocratic discourse appear when Orlando's antanaclasis on villain / villein (1.1.44-5) enables him to conclude his elder brother has "railed on [him]self" (1.1.49), is an auxiliary to Frederick's tyranny, his tyrannical behaviour mirroring and abetting the duke's in a pyramid that is not unlike what La Boétie describes as tyranny's way of perpetuating itself: "the despot subdues his subjects, some of them by means of others"(La Boétie 164). ${ }^{2}$ In another possible parallel, since his first speech is about his father's "will" (1.1.2), Orlando enters the stage as a La-Boétian heir: "There is [......] no heir so spendthrift or indifferent that he does not sometimes scan the account books of his father in order to see if he is enjoying all the privileges of his legacy or whether, perchance, his rights and those of his predecessor have not been encroached upon." (La Boétie 145) Likewise, Orlando's complaint about his brother "min[ing] [his] gentility with [his] education" (1.1.15-6) has a La-Boétian ring to it: "[nature] has less power over us than custom, for the reason that native endowment, no matter how good, is dissipated unless encouraged" (145). ${ }^{4}$ And when the play diverges from its source in removing one - financial - reason why Oliver may want to get rid of his brother, it may be saying something about sibling rivalry in general or suggesting another reason for Oliver's hatred:

I hope I shall see an end of him, for my soul - yet I know not why - hates nothing more than he. Yet he's gentle, never schooled and yet learned, full of noble device, of all sorts enchantingly beloved, and indeed so much in the heart of the world, and especially of my own people who best know him, that I am altogether misprized. (1.1.127-32, emphasis added)

6 This / these may not be exactly the same "people" as the one(s) the Duke has in mind in 1.2 and 1.3, but since Oliver's is a domestic copy of Frederick's tyranny, the speech hints at something more than jealousy, at a motive that is not just psychological but political - a political fear of his brother's desire to "mutiny against [his] servitude" (1.1.17-8) and of his rival's cross-class appeal.

7 Frederick's reason for banishing his niece is different from his more feudally-motivated dislike of Orlando (1.2.176-8), and while Le Beau may frame the Duke's "displeasure 
'gainst his gentle niece" (230) as an example of his "humorous" disposition (218), something more clearly political seems to be at work, since the ruler's displeasure is "Grounded upon no other argument / But that the people praise her for her virtues / And pity her for her good father's sake" (231-3). The Duke elaborates, telling Celia

She is too subtle for thee, and her smoothness,

Her very silence, and her patience

speak to the people and they pity her.

Thou art a fool: she robs thee of thy name

And thou wilt show more bright and seem more virtuous

When she is gone. (1.3.67-72, emphasis added)

This Machiavellian "image management" may seem like a poorly plotted excuse to ship the ladies off to Arden, but it takes on additional political significance in the proximate Shakespearean context. In Hamlet, Claudius is aware - and afraid - of his political rival of a nephew's popularity, of "the great love the general gender [i.e the people] bear him" (4.7.19), but then Denmark is an elective monarchy; in Richard II, however, the people is used as a weapon against the eponymous king by Bolingbroke (soon to be Henry IV), whose "pursuit of popularity [was] Shakespeare's invention" (Shapiro 2006: 122). It seems, then, that As You Like It is part of those Shakespeare plays that reflect on politicians' pursuit - or fear - of popularity, a word whose semantics were in flux at the time:

The meaning of the word 'popularity', familiar to us today in the sense of 'being admired by many', has undergone a sea change since Shakespeare's day. In the midsixteenth-century, it was used to describe a radical form of democracy that was the opposite of tyranny. Then, in the late 1590s, a new sense of the word emerged, having to do with courting popular favor. Shakespeare was one of the first to employ it in this sense. (Shapiro 128)

Popularity was also something of a sensitive topical issue, since Elizabeth was concerned about the ambition of the Earl of Essex who, like Shakespeare's Bolingbroke, wielded popularity as a political weapon. But then, "[i]f uncomfortable parallels could be drawn between Frederick's court and Elizabeth's, the French setting would be useful as a stalking-horse under the presentation of which the dramatist might, like the jester [5.4.91-2], shoot his wit with impunity." (Dusinberre, in Shakespeare 2006a: 48-50)

\section{"Mistake me not so much / To think my poverty is treacherous" (1.3.54-55): Pastoral-romantic-rhetorical utopia}

10 "[V]oluntary exile" (1.2.81) is some characters' answer to servitude, and no sooner has Corin ushered the ladies and the clown into the pastoral space than he complains about his master's "churlish disposition" (2.4.73) and tells the migrants: "in my voice most welcome shall you be" (80) - in other words, no sooner have the ladies entered Arden than one of the play's big issues is raised: "The question of democracy [...] is the question of voice" (Ogien and Laugier 2011: 24).

11 If realistic, anti-pastoral elements were already to be found in classical if not Renaissance pastorals (in Theocritus for example),the touches of gritty topical realism in As You Like It appear as critical of Elizabethan social hierarchy. Could it be, though, that for all the subversive allure of the "Robin Hood" (1.1.93) motif, for all the topical frisson of the play's nod at enclosures (2.4.71-5), and for all the forest's apparent 
egalitarianism and carnivalesque subversion, social and gender distinctions never really go away and/or are decisively restored in the end? After all, Shakespeare himself, as a landowner, is often assumed to have had to be on the gentry's proenclosure side - and yet, "[e]xternal evidence for [his] attitude is ambiguous but, if anything, suggests opposition to enclosure rather than support of it." (Parker 1994: 36) Besides, if we pay attention to other associations than those between the fictional action and the immediate historical context, there is another story than that of order restored to be read into the play: a rhetorical story - which, in Arden's "relentlessly literary universe" (Bates 2002: 119), is as politically significant: "Beyond laughter, logical forms of disputation permeate As You Like It for serious uses which effectively illustrate Shakespeare's characteristic blending of the social and artistic." (Magnusson 2002: 167)

I admit that I am a sophist and that I educate people.

(Plato, Protagoras: 317b)

"I profess curing it by counsel" (3.3.333): what is probably the most commented-upon aspect of the play's rhetorical story is Rosalind's education of Orlando. What is less often noted is that, in presenting herself as an expert (333), and in offering to cure Orlando of his love "madness" (331) while in fact teaching him something else through a game of role-play, Rosalind/Ganymede acts like a sophistic expert resorting to disguise and discursive tricks in order to teach (about) the tricks of discourse: "the craft of the sophist is an ancient one, but [...] its practicioners in ancient times, for fear of giving offence, adopted the subterfuge of disguising it as some other craft, as Homer and Hesiod [...] did with poetry." (Plato, Protagoras: 316d) What Rosalind teaches Orlando is how to read and speak differently, how to free himself from the prisonhouses of Petrarchan love poetry and feudal discourse - a literary and linguistic education which might well free other minds than the fictional character's, and which was a sophistic priority: "I consider, Socrates, that a most important part of a man's education is being knowledgeable about poetry. By that I mean the ability to grasp the good and bad points of a poem, to distinguish them and to give one's reasons in reply to questions." (Protagoras 338e-339a)

Rosalind, however, is not Orlando's sole educator in Arden.

Although there seems to be a lot of careless time-fleeting (1.1.95) going on in his circle, Duke Senior's reference to "This wide and universal theatre [which] / Presents more woeful pageants than the scene / Wherein we play in" (2.7.137-9), far from being a consoling cliché conducive to apolitical resignation, "explicitly calls attention to the universal perspective from which any particular scene of any particular play is implicitly perceived, and to the alternative forms and paths that people's fates can take" (Ryan 2015: 92); the pastoral retreat is thus not so much an evasion of the political as an occupation of the forest - and a re-foundation.

Indeed, the play features a capsule version of the Ciceronian founding myth, whereby the orator-civilizer's reason and eloquence help turn the state of nature into civil society, when Orlando, who has been made a little uncivil by civil society and necessity, ${ }^{5}$ enters with his sword drawn and the Duke gives him a chiastic lesson in Ardenic sociability: "Your gentleness shall force / More than your force move us to gentleness" (2.7.102-3). Jaques's concurring "And you will not be answerèd with reason, I must die" (101) makes it clear that what goes down in Arden is an "implicit experiment with "the 
rule of reason' as a principle for social harmony. Behind the logical discourse in Arden is a conjecture about the plausibility of rational disputation as a basis for social community." (Magnusson 2002: 168)

Now Duke Senior may be "too disputable" (2.5.27) for even Jaques's company, and Arden may be a space where disputation is not always as rational as it seems, but as opposed to Frederick's tyrannical court, where enemies must be destroyed or exiled, the struggles in the forest are between adversaries, not enemies - which makes it an agonistic, not antagonistic, space. ${ }^{6}$

It is, of course, also an egalitarian, democratic one - Amiens's response to the Ciceronian orator's first speech, though possibly ironic, suggests how rhetorical the duke's behaviour is: "happy is your grace / That can translate the stubbornness of Fortune / Into so quiet and so sweet a style" (2.1.18-20). The syllepsis on style (verbal style / lifestyle) hints at the porosity of the boundary between the linguistic and the extralinguistic, and Duke Senior's initial words should therefore not be dismissed as wishful thinking. Indeed, for all the contextual irony of the reference to brothers, by addressing his audience as "co-mates and brothers in exile" (1) he is doing nothing less than offering a new social contract: if language is, as Cicero had it, "both a precondition of obligation and itself a source of obligation" (Kahn 2006: 131), and in so far as a duke's word can be "great" or performative (as his brother's is in a different context, 1.3.79), the duke in exile is not so much telling himself and his listeners a soothing tale or a story meant to reshape their environment - which would be political (and Machiavellian) enough - as founding an egalitarian community.

Now the Ardenic community is nowhere near as radical as, say, Praxagora's communist-feminist utopia in Aristophanes' A Parliament of Women, whose carnivalesque is close to Shakespeare's, but its nature as an agonistic egalitarian/ democratic space might go some way toward making sense of two plot points often seen as insufficiently motivated (unless their only rationale is the teleological demand for a happy ending): the apparently irrational "conversion[s]" (4.3.131) of Oliver and of Frederick who, "After some question with [an old religious man], was converted / Both from his enterprise [of putting his brother to the sword] and from the world" (5.4.145-6). "'Twas I, but 'tis not I" (4.3.130): from tyrant brother to loving brother, Oliver's transformation, which is all the more striking for being narrated - not dramatised -, suggests Arden is an agonistic space where "[t]o accept the view of the adversary is to undergo a radical change in political identity. It is more a sort of conversion than a process of rational persuasion" (Mouffe 2005: 102). As for the fightfree resolution, which diverges from the source when a battle could just easily have been narrated (as Orlando's with the lioness in 4.3), it could be read as another philosopheme, one in keeping with La Boétie's idea that one can be rid of tyranny without an actual fight: "Obviously there is no need of fighting to overcome this single tyrant, for he is automatically defeated if the country refuses consent to its own enslavement [...]. [I]f, without any violence [tyrants] are simply not obeyed, they become naked and undone and as nothing" (La Boétie 136-7). ${ }^{7}$

\section{“Motley's the only wear" (2.7.34)}

If my mind was made of gold [...] I'd be delighted to find one of those stones which are used to test 
gold [...]. I could touch my mind to it to see whether it confirmed that my mind had been properly looked after, and then at last I'd know that I was all right and that any further testing was superfluous. (Plato, Gorgias: 486d) Roman auctoritas, in Touchstone's discourse, as if the intellectually superior court jester felt like he had to resort to "the vulgar" (5.1.42), had to vulgarize himself when he talked (to the rustics). Like his fellow corrupter of words Feste in Twelfth Night, Touchstone might be wary of language itself: "We have already gone beyond whatever we have words for. In all talk there is a grain of contempt. Language, it seems, was invented only for what is average, medium, communicable. By speaking the speaker immediately vulgarizes himself." (Nietzsche 73-4) ${ }^{8}$ The Fool's apparent contempt could also be explained in terms of the play's management of audience response: the sometimes patronised rustics in Arden would thus have a similar function to those in The Winter's Tale and be "essential if the audience is not to feel threatened by a revolutionary impulse in the play's demonstration of a better life outside the court" (Gifford 1999: 89). Incidentally, either Touchstone parodies courtiers' discourse or the play itself ironises his assertion of social superiority when the fool addresses Corin as "clown" (2.4.57), which is a synonym for "fool" - either way, the play suggests identity and equality when the character seems to assert superiority, as also happens in another cross-class carnivalesque echo, when Duke Frederick's "Mistress, dispatch you with your safest haste" (1.3.31) echoes Touchstone's own term of address: "Mistress, you must come away to your father" (1.2.46). (Plato, Sophist: 231d-e), and the sophisticated Fool uses rhetorical overkill to talk a rival out of his suit:

TOUCHSTONE [...] learn this of me: to have is to have. For it is a figure in rhetoric that drink, being poured out of a cup into a glass, by filling the one doth empty the other. For all your writers do consent that "ipse" is he. Now you are not ipse, for I am he. WILLIAM which he, sir?

TOUCHSTONE He, sir, that must marry this woman. (5.1.36-41)

If Touchstone's rhetorical practice is agonistic, this is the agonism of democracy, not antagonistic mortal combat, and William's parting words are "God rest you merry, sir" (5.1.52).

23 In his agon with Corin (3.3.1-62) about "this shepherd's life" (3.3.1), Touchstone may be voicing the play's own in utramque partem ambivalence and relativism:

CORIN And how like you this shepherd's life, Master Touchstone?

TOUCHSTONE Truly, shepherd, in respect of itself, it is a good life; but in respect that it is a shepherd's life, it is naught. In respect that it is solitary, I like it very well; but in respect that it is private, it is a very vile life. Now in respect it is in the 
fields, it pleaseth me well; but in respect it is not in the court, it is tedious. As it is a spare life, look you, it fits my humour well; but as there is no more plenty in it, it goes against my stomach. (3.3.1-8)

In Kiernan Ryan's reading of this passage,

Shakespeare compresses into Touchstone's compulsive catchphrase 'in respect of' and its variants the restless, multivocal dynamic of the entire play, which seeks to disengage us from unqualified commitment to any particular identity or standpoint we may be inclined to adopt. That structural dynamic is inherently democratic, inasmuch as it disperses authority impartially across the full range of dramatis personae, refusing to grant sovereignty to any of the positions dramatized. This is, perhaps, the most powerful way in which the comedy articulates its utopian commitment to the common interests of humanity, and to the prospect of a form of community that serves those common interests rather than the interests of one class or kind of human being at the expense of others. (Ryan 2009: 231, emphasis added)

Touchstone, who turns the dialogue into a Protagorean antilogy, makes the somewhat counterintuitive, paradoxical and anti-pastoral point that Corin is "damned" for never having been "in court" (3.3.17-20):

CORIN You have too courtly a wit for me, I'll rest.

TOUCHSTONE Wilt thou rest damned? God help thee, shallow man. [...]

CORIN Sir, I am a true labourer: I earn that I eat, get that I wear, owe no man hate, envy no man's happiness, glad of other men's good, content with my harm; and the greatest of my pride is to see my ewes graze and my lambs suck.

TOUCHSTONE That is another simple sin in you: to bring the ewes and the rams together and to offer to get your living by the copulation of cattle; to be bawd to a bell-wether and to betray a she-lamb of a twelvemonth to a crooked-pated old cuckoldly ram out of all reasonable match. If thou be'st not damned for this, the devil himself will have no shepherds. (3.3.50-62)

The dissoi logoi or double discourses offer a counterdiscourse to the play's own pastoral discourse, and as Touchstone uses Corin's arguments and words against him, with an antanaclasis on 'rest' for example (3.3.50-1), he exemplifies Feste's axiom that "A sentence is but a cheverel glove to a good wit: how quickly the wrong side may be turned outward" (Shakespeare, Twelfth Night 3.1.11-3) and displays sophistic elegance, namely "the elegance of knowing how to use the other's facts, ideas, and their very words so as to draw an opposite conclusion from them" (de Romilly 1988: 120). ${ }^{9}$

"How prove you that in the great heap of your knowledge?" (1.2.54): Celia's question sounds like a Socratic-ironical challenge to a sophist - and Touchstone delivers, proving Gorgias's point that "[a] rhetorician is capable of speaking effectively against all comers, whatever the issue" (Gorgias 457a). When the Fool, on what looks like an impossible mission, proves that the "knight that swore, by his honour" (1.2.50) that bad pancakes were good and that good mustard was bad was not forsworn, the play is also suggesting how restrictive our notions of what is possible may be - and showing how empowering and liberating paradox can be.

Touchstone, as a versatile sophist, is indeed "as good at anything, and yet a fool" (5.4.89-90). As for his famous "much virtue in "if" (5.4.88), which could be the subtitle of a play that counterfactually explores other spaces, other views and other polities than the Elizabethan ones, his speech runs against the Socratic (antidemocratic) idea that "one can best examine the question by getting rid of any 'Ifs"' (Protagoras 331d) and against Richard's tyrannical equation of if with treason: "Tell'st thou me of 'if's? Thou art a traitor." (Shakespeare, Richard III 3.4.80). The play revels in hypotheses and 
uncertainty - but then, "the domain of politics is not and cannot be the domain of the unconditional because it requires making decisions in an undecidable terrain. This is why the type of order which is established through a given hegemonic configuration of power is always a political, contestable one" (Mouffe 2013:17).

Like the Sophists, As You Like It gives its audience a civics lesson in rhetoric, and through Touchstone's sophistic displays turning pastoral values upside down and making doxa paradoxical, it implements the rhetoric of democracy, a regime in which decision is disputed (hence disputable and reversible), and where the conventionalism of names means, according to antidemocratic Platonism, that "insubordination [is called] 'erudition', disorder 'freedom', extravagance 'magnificence', and uninhibitedness 'courage”' (Plato, Republic 560e-561a).

The Fool's garb, like goodness according to Protagoras, is motley - a term that, in Plato's antidemocratic Republic, is actually a trademark of democracy with its "motley masses" (493d) and "motley crowd of people" (475d). Since, like its rhetorical jukebox of a clown, As You Like It is often described as "motley-minded" (5.4.39) itself - a motley of literary genres, modes and styles -, its only wear may very well be the motley of (ancient) democracy.

\section{"Transformed into a beast" (2.7.1): Jaques, a melancholy animal}

31 Like the Fool's motley, melancholy - the Renaissance disease of princes, artists and philosophers - can be a cover for satire, but Jaques's sadness may have a "subversive dimension" in and of itself as "sadness has the power to protest the established order"(Fœssel 2015: 22, 224). ${ }^{10}$

The "liberty" (2.7.47) the melancholiac calls for is ambiguous (glossed as "licence" by Michael Hattaway and as "freedom" or "licence" by Juliet Dusinberre in their respective editions of the play), but when he asks for "leave / To speak [his] mind" to "Cleanse the foul body of th'infected world" (58-60), though he may sound like a Puritan preacher or a Jonsonian (unShakespearean) satirist, he may also be asking for parrhesia, free speech - a trademark of radical Athenian democracy. A parrhesiastes is "someone who takes a risk", for example the risk of losing their popularity by opposing public opinion (Foucault 2016: 83), and, as it happens, Jaques's tirades do not exactly endear him to his fellow characters. Although the "old religious man" (5.4.144) has done the converting, Jaques's exit and desire to talk to the "convertites" (for "There is much matter to be heard and learned" out of them, 5.4.168-9) could therefore signal the melancholiac's move from political to philosophical parrhesia, which has conversion for its goal. ${ }^{11}$

33 Can Jaques seriously be described as a philosopher? It is something of a critical truism, after all, that Jaques's melancholy is no more than a fashionable pose and that his discourse is also discredited by his rhetorical defeats and his past identity as a "libertine" (2.7.65). Jaques is so discredited, indeed, that it is sometimes assumed that he misunderstands Touchstone's clowning and misses the puns on hour / whore etc. (26-7). And yet, how can we tell what Jaques knows? After all, "in As You Like It, Shakespeare bends the rules, creating situations where we can no longer be as confident as we'd like to be about what characters know, even who they really are" 
(Shapiro 2006: 212). Besides, traces of Shakespeare's philosopher-in-chief, Hamlet, have been found in two of the play's characters, ${ }^{12}$ and the Hamlet connection between the melancholiac and the Fool is revealing of how blurred the boundary actually is between them. Indeed, though he asks Duke Senior to "Invest [him] in [his] motley" (2.7.58), it seems that, with or without motley, Jaques is already the duke's jester. "'Tis a Greek invocation to call fools into a circle" (2.5.51): Jaques's reply to Amiens's demand for an explanation about his enigmatic "Ducdame, ducdame, ducdame" (46), for instance, plays the same kind of metaleptic trick that Feste's reference to the "picture of "we three"' (Twelfth Night 2.3.16) tries to do, i.e. implicating the spectator in the spectacle in order to make a fool or an ass of them. And when Touchstone wants to be married by Sir Oliver Martext, it is Jaques who convinces him to think twice (3.4.59-81).

It is not that easy, then, to say with certainty whether Jaques is an eiron or an alazon, a clever ironist or a fool; Shakespeare makes the melancholiac's case a puzzling one, his voice anything but a totally discredited one. This, arguably, points to another democratic feature of the play: its polyphony, its equality of discourses - the literary equivalent to isegoria, equality and freedom of speech in ancient democracy:

The universalizing imagination that finds stylistic expression in the wording and imagery of the plays finds structural expression [...] in the way Shakespeare pushes the polyphonic possibilities of Elizabethan drama to the limit, sharing the right of speech democratically between the diverse dramatis personae with scant regard for the customary proprieties, and playing havoc with hierarchy in the process. (Ryan 2015: 91)

In fact, it is as if the play's philosopher figure is split into an ironist (Touchstone) and a melancholiac: "While melancholy bears the power of the mind like a burden, irony takes the mind's powerlessness lightly. When combined, they make for courage of the mind - for philosophy." (Wilhelm Szilasi, in Starobinski 2012: 178-9) ${ }^{13}$

\section{One understands a philosopher only by heeding closely what he means to demonstrate, and in reality fails to demonstrate, concerning the limit between human and animal. \\ (Derrida 2006: 147) ${ }^{14}$}

"I think he be transformed into a beast" (2.7.1): Jaques lives on the boundary between men and animals, and Touchstone is conjured up when Duke Senior and the First lord refer to animals as "poor dappled fools" (2.1.22) and as "hairy fool[s]" (40) - he is, after all, another Fool "Much markèd of the melancholy Jaques" (41). If the Robin Hood community in Arden hunts and asserts its sovereignty through its treatment of (other) animals, the play keeps endowing the latter with human, even civic, attributes, thus blurring the line between men and animals and illustrating

\footnotetext{
the double and contradictory figuration of political man as on the one hand superior, in his very sovereignty, to the beast that he masters, enslaves, dominates, domesticates, or kills, so that his sovereignty consists in raising himself above the animal and appropriating it, having its life at his disposal, but on the other hand (contradictorily) a figuration of the political man, and especially of the sovereign state as animality, or even as bestiality (Derrida 2008: 50 ). ${ }^{15}$
}

When Jaques reportedly "swear[s] that [the Robin Hood gang] / Are mere usurpers, tyrants, and what's worse, / To fright the animals and to kill them up / In their assigned and native dwelling-place" (2.1.60-63), his lament may be undermined by the trite, iconic situation (of the melancholiac by the river) but it still packs an emotional 
punch, and Montaigne, for one, has a similar reaction: "For my own part, I cannot without grief see so much as an innocent beast pursued and killed that has no defence, and from which we have received no offence at all" (Montaigne 454). ${ }^{16}$ Sympathy for animals can turn into a questioning of human (and royal?) superiority:

But when [...] I meet with arguments that endeavor to demonstrate the near resemblance betwixt us and animals, how large a share they have in our greatest privileges, and with how much probability they compare us together, truly I abate a great deal of our presumption, and willingly resign that imaginary sovereignty that is attributed to us over other creatures. (456, emphasis added) ${ }^{17}$

"Here comes a pair of very strange beasts which, in all tongues, are called fools" (5.4.36-7): no matter what the character's intentions may be, the references to animals are a great social leveller in the play; in a twofold boundary-blurring gesture, when animals are referred to as "native burghers" (2.1.23) and as "citizens" (2.1.55) by Duke Senior and Jaques respectively, the echo brings the duke and the melancholiac closer, and the tropes blur the species boundaries between men and animals. "We owe justice to men, and graciousness and benignity to other creatures that are capable of it" (Montaigne 457): $:^{18}$ as with Orlando (1.1.5-30) and Adam (64-7), the numerous animal references in Arden can thus be read as an exploration of what politics and sovereignty are, and a call for social justice.

Isn't Jaques inconsistent in his anti-speciesism in 4.2, though? Possibly - and yet, it is far from obvious that he is calling for a celebration of hunting when he asks "Which is he that killed the deer?" (4.2.1): the presentation of the hunter as a "Roman conqueror" (3) sounds ridiculously hyperbolic, especially in a play that calls Caesar's "I came, saw, and overcame." a "thrasonical brag" (5.2.25-6); and as for "set[ting] the deer's horns upon [the hunter's] head for a branch of victory" (4.2.4-5), it is by no means obvious that the context deprives the horns of their association with cuckoldry. When Jaques asks for a song and says "'Tis no matter how it be in tune, so it make noise enough" (4.2.7), he might thus in fact be calling for a charivari casting ridicule on cuckolds - a reading which, by the way, the song's lyrics do nothing to refute.

In a speech where polysyndeton - the spectacular accumulation of coordinating conjunctions - defines his melancholy the better to evade standard definitions, Jaques asserts that his is "neither the scholar's melancholy [...]; nor the musician's [...]; nor the courtier's [...]; nor the soldier's [...]; nor the lawyer's [...]; nor the lady's [...]; nor the lover's [...]; but [...] a melancholy of [his] own, compounded of many simples, extracted from many objects" (4.1.9-14). In his search for his voice among other voices, for his plural discourse among and against other melancholy discourses, and in his very selfcontradictions, the libertine-turned-ethicist might thus show that "Searching for your voice, for truth and accuracy, involves [...] a constant rejection of conformity, including to yourself. That is the sense of a politics of the ordinary, which lies at the heart of the democratic principle" (Ogien and Laugier 2014: 254). ${ }^{19}$

41 And, if Jaques was Shakespeare's first sustained attempt at satire, it is as if both author and character were experimenting and searching for their voices in this play. Likewise, when Jaques describes the world as a stage (2.7.139), he is both acting in typical clownish fashion - by asserting his "right to live a life in [...] the chronotope of theatrical space, the right to act life as a comedy and to treat others as actors, the right to rip off masks, the right to rage at others" (Bakhtin 1981: 163, emphasis added) - and speaking for his author. No matter how many agons the melancholy Fool-cum-satirist 
loses, the polyphonic play's afterlife has made Jacques's voice one of the most memorable of voices, and his much-excerpted speech on the Seven Ages of Man (2.7.139-166) - whose derivation from Epictetus, incidentally, might also suggest we be wary of representations - has taken on authorial authority. Which makes the speech worth reconsidering:

The fact that 'All the world's a stage / And all the men and women merely players' [2.7.139-140] has become an arthritic Shakespearean cliché, routinely wheeled out to sum up the transience and vanity of human life, shouldn't blind us to the subversive implications that this view of men and women and the world harbours, and that Shakespeare's drama exploits to the full. (Ryan 2015: 92-93)

Indeed, since Jaques is not a consistent Stoic himself, the theatrum mundi speech is not necessarily about having to accept one's fate but is susceptible to a demystifying, empowering interpretation, in which identities are not fixed - neither god-given essences, nor naturally hierarchised - but are roles - theatrical, performative selves in a play whose ending is not foreordained.

\section{"If truth holds true contents" (5.4.114): Jaxit}

Spectators, if you care to spend an easy life from day to day Among us Birds, by all means come and live with us; make no delay. So many things on earth are blamed, or by convention vilipended, Which in the kingdom of the Birds are quite correct or even splendid. (Aristophanes, The Birds) ${ }^{20}$

Jaques, who may as a textual tool speak "wiser than [he is] aware of" (2.4.48) regardless of whatever we presume to know of the fictional character's knowledge, is of course not the only character on an extrametaleptic course; Rosalind is the one who is most often seen as the play's intradramatic co-author, and in the finale and epilogue, far from relinquishing control to the patriarchs by being given, she "give[s] [her]self" (5.4.101-2) - and comes into her own as an authorial actor.

Since Hymen's intervention is unnecessary plot-wise, the theophany's rationale appears to be to carnivalise the god ("Peace, ho", 5.4.109) and courtly shows: "Bridging the divide between courtly and popular theater, Shakespeare makes available to ordinary playgoers a taste of the expensive and spectacular symbolic drama of the court." (Shapiro 2006: 226) The numerous occurences of 'if' in both the finale (5.4.103-8, 114) and the epilogue ("If it be true...", 1.2; "If I were a woman", l.13) suggest the play's closure is only conditional - and indeed, by stepping outside the boundaries of fiction, "Rosalind" could in fact draw the audience toward, or metaleptically bring them into, the fiction, thereby making the play the spectators' own Forest of Arden. It is thus hard to agree that the action of As You Like It amounts to a process of enclosure, for in addition to the play's toying with, and undermining closure in the epilogue, an equally anti-homeostatic, centrifugal exit occurs: Jaques's, whose parting words (5.4.170-6) echo Hymen's (115-20) - a human echo of the divine which both brings the god down to earth and elevates Jaques to quasi-authorial status (again). 
When the restored ruler asks the melancholiac to stay (5.4.178), it sounds like "the consoler comes across as the protector of a social order that has been weakened by the anarchic expression of pain" (Fœssel 2015: 44), ${ }^{21}$ for Jaques's exit threatens the play's closure and the Duke's new order. "Disobedience lies at the foundation of democracy"(Ogien and Laugier 2011: 165)22 and, no matter what the fictional character's politics may be, Jaques's quite civil disobedience, his refusal to stay (5.4.179-80), is the play's democratic gesture: "What characterizes democratic politics is [...] a confrontation with no possibility of final reconciliation" (Mouffe 2013: 17). The open-ended play which stages difference and dissent instead of dramatically endorsing closure and hegemonic reconciliation (which incidentally is twice associated with falling, 5.4.160-1), then, is itself democratic, and when Jaques - who as a "compact of jars" (2.7.5) might be an embodiment of agonistic democracy - leaves, the melancholiac's Arden seems to be about to morph into a Walden where he can talk with the "convertites" (5.4.168) - and thus join another community: "Against conformity, Emerson and Thoreau [...] ask for [...] a life that is ours, a life we have consented to in our own voice; life as a conversation, in short - democracy." (Ogien and Laugier 2011: $32)^{23}$

\section{"This prophecy Merlin shall make, for I live before his time" (King Lear 3.2.95-6)}

[N]o deconstruction without democracy, no democracy without deconstruction.

(Derrida 2005: 105)

"Hereafter, in a better world than this" (1.2.236)... recent scholarship sometimes echoes Romantic critics and makes Shakespeare and As You Like It prophetic: it "was a play not only of its time but also ahead of it" according to James Shapiro (204), and for Juliet Dusinberre, "[a]lthough the play is rooted in Elizabethan culture [...] Shakespeare has placed a prophetic finger on the pulse of the future." (Dusinberre, in Shakespeare 2006a: 1) In political terms, thinking ahead and thinking outside the box are the nexus of philosophical Shakespeare's "revolutionary universalism". ${ }^{24}$

The history of the play's reception, and the critical story of its meanings, are only 400 years old, and will go on being lived and written: "Oh! democracy! whither, oh! whither are you leading us?" 25 - Where we like it.

\section{BIBLIOGRAPHY}

Aristophane. Les Oiseaux. In Théâtre complet II. Victor-Henry Debidour (ed.). Paris: Gallimard, 1966.

Bakhtin, Mikhail. The Dialogic Imagination. Michael Holquist (ed.). Trans. Caryl Emerson and Michael Holquist. Austin: U. of Texas P., 1981. 
Bakhtin, Mikhail. Speech Genres and Other Late Essays. Caryl Emerson and Michael Holquist (ed.). Trans. Vern W McGee. Austin: U. of Texas P., 1986.

Bates, Catherine. "Love and courtship". In Alexander Leggatt (ed.). The Cambridge Companion to Shakespearean Comedy. Cambridge: Cambrige UP, 2002.

Cascardi, Anthony J. The Cambridge Introduction to Literature and Philosophy. New York: Cambridge UP, 2014.

De Romilly, Jacqueline. Les Grands Sophistes dans l'Athènes de Périclès. Paris: Editions de Fallois/Le Livre de Poche, 1988.

Derrida, Jacques. The Politics of Friendship. London: Verso, 2005.

Derrida, Jacques. L'animal que donc je suis. Paris: Editions Galilée, 2006.

Derrida, Jacques. La bête et le souverain. Vol. I. Paris: Editions Galilée, 2008.

Dupont, Florence. "Cicéron, sophiste romain". Langages, $\mathrm{n}^{\circ} 65$, Signification et référence dans l'antiquité et au moyen âge, 1982. 23-46. http://www.persee.fr/doc/

lgge_0458-726x_1982_num_16_65_1118

Elam, Keir. Shakespeare's Universe of Discourse. Language-Games in the Comedies. Cambridge: Cambridge UP, 1984.

Erne, Lukas. Shakespeare as Literary Dramatist. Cambridge: Cambridge UP, 2013.

Fœssel, Michaël. Le Temps de la consolation. Paris: Editions du Seuil, 2015.

Foucault, Michel. Discours et vérité. Paris: Librairie Philosophique J. Vrin, 2016.

Gifford, Terry. Pastoral. London: Routledge, 1999.

Hadfield, Andrew. Shakespeare and Republicanism. Cambridge: Cambridge UP, 2008.

Kahn, Victoria. "Rhetoric, Rights, and Contract Theory in the Early Modern Period". In Walter Jost and Wendy Olmsted (ed.). A Companion to Rhetoric and Rhetorical Criticism. Oxford: Blackwell, 2006.

Kott, Jan. Shakespeare our Contemporary. New York: Norton, 1974.

(De) La Boétie, Etienne. Discours de la servitude volontaire. Paris: Flammarion, 1983.

Magnusson, Lynne. "Language and comedy". In Alexander Leggatt (ed.). The Cambridge Companion to Shakespearean Comedy. Cambridge: Cambrige UP, 2002.

Montaigne. “De la cruauté”. In Les Essais II.xi. Paris: Editions Gallimard, 2007.

Montrose, Louis Adrian. "'The Place of a Brother' in As You Like It: Social Process and Comic Form”. Shakespeare Quarterly 32(1) Spring, 1981: 28-54.

Mouffe, Chantal. The Democratic Paradox. London: Verso, 2005.

Mouffe, Chantal. Agonistics. Thinking the World Politically. London: Verso, 2013.

Nietzsche, Friedrich. Crépuscule des idoles. Trans. Jean-Claude Hémery. Paris: Gallimard, 1974.

Ogien, Albert and Sandra Laugier. Pourquoi désobéir en démocratie ? Paris: La Découverte, 2011.

Ogien, Albert and Sandra Laugier. Le principe démocratie. Enquête sur les nouvelles formes du politique. Paris: Editions La Découverte, 2014.

Plato. Sophist. Trans. Nicholas P. White. Cambridge: Hackett, 1993.

Plato. Gorgias. Trans. Robin Waterfield. Oxford: Oxford UP, 1994. 
Plato. Republic. Trans. Robin Waterfield. Oxford: Oxford UP, 1998.

Plato. Protagoras. Trans. Christopher C.W. Taylor. Oxford: Oxford UP, 2002.

Platt, Peter G. "Shakespeare and Rhetorical Culture". In David Scott Kastan (ed.). A Companion to Shakespeare. Oxford: Blackwell, 1999.

Puttenham, George. The Art of English Poesy. Frank Whigham and Wayne A. Rebhorn (ed.). Ithaca: Cornell UP, (1589) 2007.

Romeyer Dherbey, Gilbert. Les sophistes. Paris: P.U.F, 2012.

Ryan, Kiernan. Shakespeare's Comedies. Basingstoke: Palgrave Macmillan, 2009.

Ryan, Kiernan. Shakespeare's Universality. Here's Fine Revolution. London: Bloomsbury, 2015.

Sabot, Philippe. Philosophie et littérature. Approches et enjeux d'une question. Paris: P.U.F, 2002.

Shakespeare, William. Coriolanus. Brian Parker (ed.). Oxford: Oxford UP, 1994.

Shakespeare, William. King Lear. Reginald A. Foakes (ed.). Walton-on-Thames: The Arden

Shakespeare, Thomas Nelson, 1997.

Shakespeare, William. Richard III. John Jowett (ed.). Oxford: Oxford UP, 2000.

Shakespeare, William. As You Like It. Juliette Dusinberre (ed.). London: The Arden Shakespeare, Thomson Learning, 2006.

Shakespeare, William. Hamlet. Ann Thompson and Neil Taylor (ed.). London: The Arden Shakespeare, Thomson Learning, 2006.

Shakespeare, William. Twelfth Night. Keir Elam (ed.). London: The Arden Shakespeare, Cengage Learning, 2008.

Shakespeare, William. As You Like It. Michael Hattaway (ed.). Cambridge: Cambridge UP, 2009.

Shapiro, James. A Year in the Life of William Shakespeare. 1599. New York: Harper Perennial, 2006.

Starobinski, Jean. L'Encre de la mélancolie. Paris: Editions du Seuil, 2012.

Wilson, Richard. "'Like the Old Robin Hood': As You Like It and the Enclosure Riots". Shakespeare Quarterly 43(1) Spring, 1992: 1-19.

\section{NOTES}

1. As You Like It, 1.1.17-18. All references to the play are to Michael Hattaway's New Cambridge edition (Shakespeare 2009).

2. "[L]e tyran asservit les sujets les uns par le moyen des autres" (English translation by Harry Kurz).

3. "[I]l n'est point d'héritier si prodigue et nonchalant que quelquefois ne passe les yeux sur les registres de son père, pour voir s'il jouit de tous les droits de sa succession, ou si l'on a rien entrepris sur lui ou son prédécesseur." (Translation by H. Kurz).

4. "[La nature] a en nous moins de pouvoir que la coutume : pour ce que le naturel, pour bon qu'il soit, se perd s'il n'est entretenu" (translation by H. Kurz).

5. "Through a kind of paradox that Rousseau too came upon, nature in Hippias's view creates a sociability that is destroyed by none other than society" ("Par une sorte de paradoxe que retrouvera Rousseau, la nature aux yeux d'Hippias crée une sociabilité que précisément la société détruit", Romeyer Dherbey 2012: 88). 
6. "Antagonism is struggle between enemies, while agonism is struggle between adversaries" (Mouffe 2005: 102-3).

7. “Encore ce seul tyran, il n'est pas besoin de le combattre, il n'est pas besoin de le défaire, il est de soi-même défait, mais que le pays ne consente à sa servitude [...]. [S]i on [n'] obéit point [aux tyrans], sans combattre, sans frapper, ils demeurent nus et défaits et ne sont plus rien" (translation by H. Kurz).

8. “Ce pour quoi nous trouvons des paroles, c'est que nous l'avons dépassé. Dans tout discours, il y a un soupçon de mépris. La langue, semble-t-il, n'a été inventée que pour les choses médiocres, communes, communicables. Par le langage, celui qui parle se vulgarise." (Nietzsche 73-74; English translation by Walter Kaufman and R.J.Hollingdale)

9. “[L]'élégance [...] de savoir reprendre à l'autre ses faits, ses idées et ses mêmes mots pour en tirer une conclusion inverse".

10. "[L]a tristesse constitue une puissance de contestation de l'ordre établi".

11. According to Michel Foucault, the aim of philosophical parrhesia (as against political parrhesia) is "conversion", "convincing someone that they should take care of themselves and change their lifestyle" ("convaincre quelqu'un qu'il doit prendre soin de lui-même et changer de vie", 221).

12. "Before Jaques turns into Hamlet he must first go through the school of clowning. [...] Before a philosophical clown [like Touchstone] can become Hamlet, he must find personal reasons for his bitterness" (Kott 1974: 285).

13. "De même que la mélancolie porte la puissance de l'esprit avec lourdeur, l'ironie prend l'impuissance de l'esprit d'un coeur léger. L'unité des deux est le courage de l'esprit ; c'est la philosophie."

14. "On ne comprend un philosophe qu'à bien entendre ce qu'il entend démontrer, et en vérité échoue à démontrer, de la limite entre l'homme et l'animal." (English translation by David Wills) 15. "la double et contradictoire figuration de l'homme politique comme, d'une part, supérieur, dans sa souveraineté même, à la bête qu'il maîtrise, asservit, domine, domestique ou tue, si bien que la souveraineté consiste à s'élever au-dessus de l'animal et à se l'approprier, à disposer de sa vie, mais, d'autre part (contradictoirement), figuration de l'homme politique, et notamment de l'État souverain comme animalité, voire bestialité." (English translation by Geoffrey Bennington)

16. "De moy, je n'ay pas sceu voir seulement sans desplaisir, poursuivre et tuer une beste innocente, qui est sans deffence, et de qui nous ne recevons aucune offence." (English translation by Charles Cotton)

17. "Mais quand je rencontre [...] les discours qui essayent à montrer la prochaine ressemblance de nous aux animaux : et combien ils ont de part à nos plus grands privileges ; et avec combien de vray-semblance on nous les apparie ; certes j'en rabats beaucoup de nostre presomption, et me demets volontiers de cette royauté imaginaire, qu'on nous donne sur les autres creatures." (Translation by Charles Cotton)

18. "Nous devons la justice aux hommes, et la grace et la benignité aux autres creatures, qui en peuvent estre capables" (Translation by Charles Cotton).

19. "La recherche de la voix, de la justesse, est [...] le rejet permanent de la conformité, [...] y compris à soi-même. Tel est le sens d'une politique de l'ordinaire, qui est au coeur du principe démocratie".

20. "Si tel de vous, Messieurs les Spectateurs, veut parmi les oiseaux se tisser pour l'avenir une vie de délices, qu'il vienne donc me trouver ! Car tout ce qui est ici [à Athènes] réprimé par la loi, comme indigne, tout ça, chez nous autres les oiseaux, c'est excellent." (Aristophane 70; English translation by George G.A. Murray)

21. "Le consolateur se présente [...] comme le garant d'un ordre social fragilisé par l'expression anarchique de la douleur".

22. "[L]a désobéissance est au fondement de la démocratie". 
23. "Contre la conformité, Emerson et Thoreau [...] demandent [...] une vie qui soit à nous, à laquelle nous ayons consenti, avec notre propre voix : une vie comme conversation, bref la démocratie."

24. "[The] profound commitment to the universal human potential to live otherwise is the secret of the plays' proven ability to transcend their time. This is what drives their radical dissatisfaction with Shakespeare's world, divorcing their vision from the assumptions and attitudes that held sway in early modern England, and opening them up to the future and the prospect of the world transfigured. That prospect - the tidal pull of futurity that inflects their language and form at every turn - is what propels Shakespeare's plays beyond the horizon of his age to speak with more authority and power than ever to ours. The timelessness of the plays springs from their refusal to make complete sense in the terms of their time, which they view from the vantage point of a future we ourselves can only imagine." (Ryan 2015: 9-10)

25. "Sainte Démocratie, où nous mèneras-tu?" (Aristophane 112; English translation by Eugene O’Neill Jr).

\section{ABSTRACTS}

With philosophers from the Sophists and Plato, through La Boétie and Montaigne, to Jacques Derrida and Chantal Mouffe as its main context, this paper examines a number of politicalphilosophical aspects of Shakespeare's As You Like It: its representation of tyrants; the politics of its pastoral mode; its fool's sophistic rhetoric; and its political animal of a melancholiac, whose exit in the last scene problematizes the apparently conservative restoration. In light of this attempt to think not just about the play but with the play, and to trace the subtleties of its literary thinking or its thinking as literature, it appears that what As You Like It has in common with sophistic practice and democratic theory enables it to look beyond its immediate historical context to a future that could extend beyond our present, and give us food for democratic thought.

Avec pour contexte principal des philosophes, des Sophistes et Platon à Jacques Derrida et Chantal Mouffe, en passant par La Boétie et Montaigne, cet article étudie certains aspects de la philosophie politique de Comme il vous plaira de Shakespeare : sa représentation de la tyrannie, les aspects politiques de son mode pastoral, la rhétorique sophistique de son bouffon, et son mélancolique animal politique Jaques, dont la sortie lors de la dernière scène problématise une restauration en apparence conservatrice. À la lumière de cette réflexion sur la pièce, mais aussi avec elle, qui tente de suivre les lignes subtiles de sa pensée littéraire, ou de son penser en tant que littérature, ce que Comme il vous plaira semble avoir en commun avec la pratique sophistique et la théorie démocratique lui permet de porter le regard au-delà de son contexte historique immédiat vers un avenir qui pourrait dépasser notre présent, et donner matière à réflexion démocratique. 
INDEX

Mots-clés: sophistes, démocratie, rhétorique, littérature, philosophie, Shakespeare William, Comme il vous plaira

Keywords: sophists, democracy, rhetoric, literature, philosophy, Shakespeare William, As You Like It

\section{AUTHOR}

\section{IFIG COCOUAL}

Ifig Cocoual teaches classes préparatoires (khâgne) at Victor Duruy High School in Paris. He has written several articles on Shakespeare as well as an article on Margaret Atwood's The Handmaid's Tale (in Études canadiennes). Contact: icocoual[at]aol.com 